\title{
Article
}

\section{Drawing the city - writing the city: Analogue as linguistic form}

\author{
McEwan, Cameron
}

Available at http://clok.uclan.ac.uk/22140/

McEwan, Cameron ORCID: 0000-0002-0683-1708 (2018) Drawing the city writing the city: Analogue as linguistic form. Drawing: Research, Theory, Practice, 3 (1). pp. 29-45. ISSN 2057-0384

It is advisable to refer to the publisher's version if you intend to cite from the work. http://dx.doi.org/10.1386/drtp.3.1.29_1

For more information about UCLan's research in this area go to

http://www.uclan.ac.uk/researchgroups/ and search for <name of research Group>.

For information about Research generally at UCLan please go to http://www.uclan.ac.uk/research/

All outputs in CLoK are protected by Intellectual Property Rights law, including Copyright law. Copyright, IPR and Moral Rights for the works on this site are retained by the individual authors and/or other copyright owners. Terms and conditions for use of this material are defined in the policies page.

\section{CLoK}

Central Lancashire online Knowledge www.clok.uclan.ac.uk

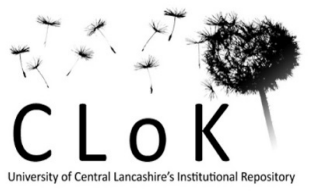




\section{Drawing the City - Writing the City: The Analogue as a Linguistic Form}

\section{Introduction}

'The obsession for symbols that lies deep inside me is like a yearning for a language limited to only a few words.'

Charles-Edouard Jeanneret, Journey to the East, 1911/1966.

'I recognize in many of my drawings, a type of drawing where the line is no longer a line, but writing.'

Aldo Rossi, A Scientific Autobiography, 1981.

When Aldo Rossi developed the concept of the analogical city in the 1960s and 1970s it was by means of an intense engagement of drawing and writing that condensed into one another, 'where the line is no longer a line, but writing,' and where the city itself became an 'historical text. ${ }^{, 1}$ Rossi argued the city is an historical text made readable by means of its permanent urban types and their formal associations and syntactic relationships. At the centre of Rossi's argument was the linguistic concept of the analogical city. With the analogical city, Rossi put forward the city modelled on language as a way to unite architecture and the city, the conscious and the unconscious, individual authorship and the collective imagination. Contrary to most

\footnotetext{
${ }^{1}$ For the former statement refer Rossi's A Scientific Autobiography, p. 44. Leading up to this statement Rossi writes: 'To forget architecture, or any proposition, was the objective of my unchanging choice of a typology of pictorial and graphic construction in which the graphics became confused with handwriting, as in certain highly developed forms of graphic obsession where the marks may be seen as either drawing or writing.' (p. 43). In The Architecture of the City, Rossi says, 'cities become historical texts.' (p. 128).
} 
critics of Rossi's analogical city, I argue that the concept always refers beyond itself toward a collective and critical project of the city.

The aim of this article will be to test the possibility of Rossi's analogical city as a critical device to reassert the city as a discourse and to develop the analogue as a theoretical and methodological project. I here propose the term linguistic form to frame the discussion and construct a genealogy of the analogical city that connects Giovanni Battista Piranesi's Campo Marzio with Le Corbusier's Ville Contemporaine and Rossi's Analogical City: Panel. While it is common to link Le Corbusier's project as an analogue of Paris, as Stanislaus von Moos has commented, 'the Ville Contemporaine depends on Paris' (Von Moos 2009: 179), I will instead close-read Le Corbusier with Piranesi. In Piranesi, Le Corbusier and Rossi, drawing is a critical method to capture elements of the city that become the generative material and singular grammar for a critical project. In each of these architects' projects there is a strong dialogue between drawing and writing the city, and an emphasis on visual-based argument toward a critical interpretation of the city. A crucial component of this article is to develop a visual argument with a suite of montages by the author (Figures 1 to 4), which I refer to as montage panels. There is a dialogue between the images and the development of critical categories including: analogue, linguistic form, association, syntax, analogical gaze, and singularity. The categories and the montage panels circumstantiate a reading of the analogical city and its genealogy as a linguistic form to be read, deciphered, redefined and rewritten.

While the focus is a close-reading of the Ville Contemporaine, the argument is organised in three sections. The first section, entitled 'Writing the City: Analogue, Association, Syntax. Canaletto, Rossi, Piranesi,' situates Rossi's concept of the analogical city as a linguistic and visual model of thought and links the collage project of the Analogical City: Panel with Piranesi's Campo Marzio. The second section, called 'Drawing the City: Singularity, Analogical Gaze, Urban Grammar. Le Corbusier and Piranesi' links the analytical view with which Le Corbusier and Piranesi study Rome in their respective projects, 'The Lesson of Rome' 
of Toward an Architecture and the 'Views of Rome' by Piranesi. The concept of singularity is developed in relation to the analogical gaze that identifies and transforms the architecture of the city toward an urban grammar. The last section, 'The Ville Contemporaine as an Analogical City' puts a close-reading of the Piranesian and classical elements of Le Corbusier's Ville Contemporaine plan. The conclusion is subtitled 'The Linguistic Form of the City' and I end with the need to reassert a linguistic approach to architecture and the city with its attendant critical, representational and collective ethos against current instrumental and individualistic discourse.

\section{Writing the City: Analogue, Association, Syntax. Canaletto, Rossi, Piranesi}

One of Rossi's early readings of the analogical city is in his 1969 preface to the second Italian edition of The Architecture of the City. ${ }^{2}$ Rossi illustrates his text with a capriccio painting by Giovanni Antonio Canaletto, in which Canaletto transposes buildings by Palladio from Vicenza to the site of the Rialto Bridge in Venice then paints the scene as if it were an existing situation. In Rossi's preface he comments on the possibility of analogy as a 'logical-formal operation' and that Canaletto's painting constitutes an 'analogous Venice formed of specific elements associated with the history of both architecture and the city' (Rossi 1982: 166). Rossi goes on to say that the 'transposition' of buildings within the painting constitutes 'a place of purely architectural references' (Rossi 1982: 166). The keywords here - logical, formal, element, and associative - constitute the set of terms to write the analogical city. By logical Rossi puts forward the analogical city based on critical principles; he affirms a formal operation; and implies the relational process of association to connect different elements from different cities.

In the Canaletto painting textual ideas are condensed. On one hand Canaletto's logic of association can be read at the scale of the city where we look at a scene recognisably Venice

\footnotetext{
${ }^{2}$ Refer Aldo Rossi, 'Preface to the Second Italian Edition' [1969], in The Architecture of the City, pp. 164-67.
} 
with Palladio's design for the Rialto Bridge at the centre of the view. Yet simultaneously there is an association with the Verona of Palladio because the buildings that frame the view are built in Verona and not Venice. There is a question of what city do we look at, or better, on what 'ground' are we to read the scene? How are the monuments liberated from their ground? What is displaced or replaced? On the other hand there is an associative logic at the scale of the singularity of architectural form. Canaletto uses only buildings by Palladio with their language of classical order and appearance of harmony. The associative chain that links Canaletto's selection of Palladio's buildings and the transposition to the Venice situation uses a linguistic process of identification, replacement and substitution. ${ }^{3}$ Canaletto substitutes the Palazzo Chierecati for the Palazzo dei Tedeschi. He displaces the Vicenza Basilica for the Palazzo dei Camerlenghi. Canaletto replaces Antonio da Ponte's Rialto Bridge for Palladio's bridge design. A formal operation of substitution and replacement of singular architectural forms is staged: the existing Rialto Bridge is replaced by a bridge by Palladio and one palazzo is substituted for another. If there is a coherent logic to these substitutions - bridge for bridge, palazzo for palazzo - the insertion of the Basilica is less straightforward because it does not replace an existing Basilica, but another palazzo. Yet by limiting the architecture to Palladio, Canaletto writes the city with a singular coherent urban grammar.

The formal operations represented in Canaletto's painting are developed in Rossi's drawings and collages in which singular elements are repeated, duplicated and displaced from one drawing to the next, from one project to the next and are in dialogue with Rossi's own projects and the history of the city. A tower is substituted for a coffee pot or the Statue of San Carlone. The surface of the city is replaced by the surface of a table top. The square windows of Gallaratese are repeated at San Rocco and can be substituted for cross framed windows of a farm house or Milanese tenement. The analogical city built on language is a language that

\footnotetext{
${ }^{3}$ In the following discussion I draw on Lorens Holm's argument in his "Aldo Rossi and the Field of the Other" chapter of Architecture and the Unconscious, ed. by John Shannon Hendrix and Lorens Eyan Holm (London: Routledge, 2016).
} 
coheres through the analogic of formal and syntactic association and operations of replacement and substitution, combination and recombination.

The project in which the analogical principles of formal association and syntax become most intense is Rossi's Analogical City: Panel. ${ }^{4}$ (Figure 1) The collage project is a model of associative thought on the collective knowledge of architecture and puts forward a connection to architecture as the sum of all authors and projects, passing from the Greek City and Knossos, to Palladio and Ideal Cities, to Piranesi and Le Corbusier, of 'every project imagined, designed or built' to quote Rossi from elsewhere. ${ }^{5}$

The panel is composed within a square frame. This is an important syntactic operation for Rossi. The square implies centrality and this centrality produces an association with the Renaissance Ideal City, an idea reinforced by the fragment of a centrally planned circular Ideal City positioned within the upper right quadrant. The square frame is duplicated within the collage as a cross-framed window on the left, which reflects the quadrants of the city. The plan of Knossos Palace is positioned inside the window and it is possible to read a reference to Alberti's city-house analogy in this strategy of scaling. Yet Rossi puts forward a critique of centrality and any linear process of scaling because the collage is also multi-centred and mixes scales. The many centres are distinguished as large scale buildings such as the gridded blocks of San Rocco, an over scaled Segrate wall that divides the panel axially and a triangular fragment of Modena Cemetery superimposed onto the Ideal City plan.

Rossi develops an idea of critical discontinuity. He challenges the view of continuity by montaging architectural projects at different scales onto the fabric, thereby rupturing the normative notion of contextual continuity. Yet this rupturing is not without structure. There is a clear vertical axis defined by the wall of Segrate, carefully positioned large and small forms as

\footnotetext{
${ }^{4}$ Aldo Rossi, 'La Città Analoga: Tavola / The Analogous City: Panel', Lotus International, 13 (1976), 4 9.

${ }^{5}$ Aldo Rossi, 'Introduction to “Architecture, Essai Sur L'art”' [1967], UCLA Architecture Journal, 2 (1989), 40-49 (p. 43).
} 
areas of focus and a tension between the square frame and the circular form of the Ideal City fragment. While the squareness of the panel suggests a plan, the panel is not entirely a plan. The plan at the top half of the panel merges into an elevation of Gallaratese at the midpoint of the collage. Gallaratese becomes a horizontal datum and connects to a mountain terrain, behind which is a fragment of Piranesi Carceri. The panel includes narrative and iconographic representations such as the Tanzio da Varallo painting in the top right with the pointing finger as well as geometric solids - such as those drawn by Le Corbusier in the Lesson of Rome falling from the panel in an oblique direction from centre to lower right.

The critique of continuity, the multi centred composition, and the careful positioning of large figures to create axes is similar to the formal structure of Piranesi's Campo Marzio. Both the Analogical City: Panel and the Campo Marzio Ichnographia counterposition the stability of a square frame and the instability of a figure-figure relationship within the frame. Piranesi's Campo Marzio and the Analogical City share a language of intense counterpositioning of architectural forms, a combination of architectural conventions - Campo Marzio includes a plan of Rome etched onto a giant stone as if it is part of the city thereby destabilising ideas of scale, temporality and place - and both projects share a sense of historical consciousness using the history of the city as the material of their architecture.

Rossi includes fragments of Piranesi's projects within the Analogical City collage. Piranesi's Carceri, with its critique of perspectival space is inserted into the lower half of the collage. Furthermore it is possible to substitute the large urban complexes in Piranesi's Campo Marzio for the large urban artefacts in Rossi's Analogical City: Castel Sant'Angelo replaces Modena Cemetery or the Horti Sallustiani replaces San Rocco - a funerary complex for cemetery, a courtyard complex for courtyard urban form. In the upper right hand side of the Analogical City, the top right panel of Piranesi's Ichnographia is used as a background and we can see Piranesi's labyrinthine Baths complex next to Tanzio da Varallo's David. Here Rossi substitutes the head of Goliath for a pointing finger. This seems related to Rossi's repeated 
insertion of the Hand of San Carlone into his drawings, where the hand does not stand for a transcendental ideal but a political gesture toward the city as a locus of collective memory, inhabited by a thinking, imagining and creating Multitude.

The Analogical City panel is a demonstration of formal knowledge and a model of architecture's collective intelligence. Each form in the Analogical City is composed as a word within a city text. Each form refers to a chain of associations that speaks to architecture's history. ${ }^{6}$ Dialogues are constructed through processes of association and syntax. This demonstration of formal knowledge coincides with the demonstration of principles in Le Corbusier's Ville Contemporaine, which extends a linguistic approach to the city.

\section{Drawing the City: Singularity, Analogical Gaze, Urban Grammar. Le Corbusier and}

\section{Piranesi}

It is possible to situate Le Corbusier's linguistic approach to the city with his so called Journey to the East, the voyage, of $1911 .^{7}$ His notebooks of the journey compile city drawings and city writings to appropriate singular parts of the world, grasp themes and accumulate formal knowledge as elements for a language of architecture and the city. Le Corbusier draws Vienna, Bucharest, Rome, their skylines and objects. He draws the Parthenon and the Roman Forum. The architecture of the city is distilled into objects and elements that here we will call singularities.

In a crucial statement that helps elucidate Le Corbusier's linguistic approach he writes the following: 'The obsession for symbols that lies deep inside me is like a yearning for a language limited to only a few words: [...] the organisation of stone and timber, of volumes, of

\footnotetext{
${ }^{6}$ Beatriz Colomina has quoted de Saussure on images that embody multifarious signifieds that reflect back to their different viewing subjects multiple associations. Refer Beatriz Colomina, Privacy and Publicity: Modern Architecture as Mass Media (Cambridge, Mass.: MIT Press, 1994).

${ }^{7}$ Refer Le Corbusier (Charles-Edouard Jeanneret), Journey to the East, ed. \& trans. by Ivan Zaknic (Cambridge, Mass.: The MIT Press, 2007).
} 
solids and voids $[\ldots]$ and I think that such elements, are these very words, which possess infinite meaning, do not need to be clarified, since such a word, in its complete and powerful unity, expresses them all' (Le Corbusier 1966: 176). The keywords here are: a language limited to only a few words in complete and powerful unity. Architectural language is limited to the identification of singular and unified forms and elements: volumes, solids, voids, their 'organisation' or in different terms, their syntax. Le Corbusier writes: 'Beholding the Parthenon, its mass, columns, and architraves, will satisfy me as does the sea itself - and nothing else but this word' (Le Corbusier 1966: 176). The Parthenon is understood by Le Corbusier as a singular word toward the development of an urban grammar, an idea I will elaborate in relation to Le Corbusier's reading of Rome.

Le Corbusier visited Rome during the voyage, drawing the city and collecting postcards of the monuments. ${ }^{8}$ His analysis is documented in the chapter entitled 'The Lesson of Rome' in Toward an Architecture, which is illustrated with a suite of images that move from overall composition to singular object and can be read as Le Corbusier's analogical gaze toward a critical project. ${ }^{9}$ (Figure 2) The chapter frontispiece shows Hadrian's Villa at Tivoli, a collage of singular objects in careful composition, which Piranesi later produced in an etching in 1780. Then, the Pyramid of Cestius, the Coliseum, the Arch of Constantine and the Pantheon are represented as singular objects depicted in isolation without their context. The serial nature of these images is similar to the seriality of language to accumulate a formal vocabulary 'limited to a few words,' as Le Corbusier said in the statement above. Each of the monuments depicted in these images become word-forms in a grammar of the city and I will come back to this in a moment. Concluding the chapter is Le Corbusier's study of Pirro Ligorio's Antiquae Urbis Imago juxtaposed with Le Corbusier's studies of elementary solids. The solids mediate between the historical objects that Le Corbusier reproduces, with their decoration, ornament and

\footnotetext{
${ }^{8}$ Refer Colomina, Privacy and Publicity, p. 90.

${ }^{9}$ Refer Le Corbusier, Toward an Architecture, trans. by John Goodman (London: Frances Lincoln, 2008), pp. 193-200.
} 
historical accretion, and the objects themselves as distilled and unified elements. In the study of Ligorio's Urbis Imago, architectural monuments are assembled as singular objects in the city. While in Ligorio's original drawing the monuments are assembled tightly together, a formal structure that Piranesi develops in his Campo Marzio Ichnographia, in Le Corbusier's drawing, he has traced different parts of the Urbis Imago, spacing out the monuments and combining alternate parts of the image.

Le Corbusier's Urbis Imago can be read as an analogue of his future projects. The overall spatial arrangement is of objects in a park, which anticipates the concept of the Ville Contemporaine. The pyramidal and curved elements suggest the roofscape of projects such as the Assembly Building at Chandigarh or La Tourette. The Castel Sant'Angelo anticipates the Mundaneum project with its cubic form and labyrinthine plan. The angular returns of the piazza and the cut of the Coliseum at the top left of the image can be read on one hand as the orthogonal redents of the Ville Contemporaine or the fragments of Ilot Insalubrious in Paris and on the other hand the curved redents at Algiers. The curving wall that defines the River Tiber can be read as the Carpenter Centre ramp at one scale or a fragment of the sweeping inhabited highway at Algiers at another scale or the lines of infrastructure at the Ville Contemporaine.

When Le Corbusier studies Rome, he sees objects, the urban scale, a unity of form, points within the city and an urban grammar of singularities. To reinforce his argument, Le Corbusier manipulates the images. ${ }^{10}$ He crops them, deleting parts of the image, duplicating other parts, flipping, adding or subtracting elements from individual photos, cutting out and rescaling fragments. The images become abstract, distilled and singular forms. Each image discards the surrounding context to put the singularity of architecture into sharpened relief. On one hand the images are contextless because the architecture is presented as an autonomous form. On the other hand the images develop their own context internal to Le Corbusier's

\footnotetext{
${ }^{10}$ Jean-Louis Cohen shows a selection of the original postcard and Alinari photographs in his introduction to the 2008 edition of Toward an Architecture. As does Colomina in Privacy and Publicity. Refer in particular to the chapter 'Photography.'
} 
development of an urban grammar. They construct a project by developing a language against their context to open up the possibility of redefining context according to their own grammar.

The process of focusing on particular city parts and exaggerating their singularity corresponds with the process undertaken by Piranesi in his series of vedute, the 'Views of Rome. ${ }^{11}$ In 1915 Le Corbusier visited the Bibliotheque Nationale to trace Piranesi's projects. ${ }^{12}$ Le Corbusier traced Piranesi's Views of Rome, creating an inventory of monumental singular forms including those selected to illustrate the Lesson of Rome chapter. While Le Corbusier edits out the surrounding context to make architecture stand out as an autonomous form, Piranesi exaggerates the scale of architecture. If we select the same monuments that Le Corbusier identifies, we can see in Piranesi's etchings a similar process: the Coliseum fills the page, the Pyramid of Cestius dominates its setting, the Arch of Constantine is monumentalised, the Pantheon is exaggerated within its context so that the surroundings are completely removed. In this sense Piranesi's etchings and Le Corbusier's images in the Lesson chapter are analogous. Le Corbusier distils his experience of Rome and the monumental forms of Ligorio and Piranesi into simple geometries and distilled forms. They become word-forms to be combined and recombined in different ways and in different projects to develop a grammar of the city, which is close to what Le Corbusier noted in his Journey diary: 'I would prefer geometric combinations, the square, the circle, and proportions in simple and distinctive ratios' (Le Corbusier 1966: 177). The variety of forms drawn in Le Corbusier's Urbis Imago study and the grammar 'learned from Rome' is figured forth in the accumulation of singular forms and critical strategies of scaling, distilling, substitutinf, replacing, combining and recombining staged in the Ville Contemporaine.

\footnotetext{
${ }^{11}$ See for example John Wilton-Ely, The Mind and Art of Giovanni Battista Piranesi (London: Thames and Hudson, 1988).

${ }^{12}$ See Le Corbusier Before Le Corbusier: Applied Arts, Architecture, Painting and Photography, 19071922, ed. by Stanislaus von Moos and Arthur Rüegg (New Haven: Yale University Press, 2002).
} 


\section{The Ville Contemporaine as an Analogical City}

The Ville Contemporaine is an inventory of formal knowledge on the city. ${ }^{13}$ It is a catalogue of singular urban elements - cruciform towers, set-back redents, urban blocks, z-plan factories - to be disarticulated, modified, fragmented and rearticulated for other contexts. It condenses formal principles of unity and singularity from the Lesson of Rome and the principles of hierarchy, axiality and composition from Piranesi's Campo Marzio. Le Corbusier activates historical consciousness and formal knowledge by using the history of architecture as the material for his projects. The Ville Contemporaine becomes an analogical city that glances backward to Piranesi's Campo Marzio and the history of architecture, Rome, the Classical, while simultaneously forward to Rossi's analogical city.

The suite of montage studies test the analogue as a critical device (Figure 3 and 4). The montages position classical figures into Le Corbusier's Ville Contemporaine: the double square as the 'regulating lines' of the temple that Le Corbusier reproduces in Toward an Architecture are an analogue of the rectangular plan of the Ville Contemporaine with its lines of infrastructure. The section of the temple, within which is a square and triangle, connote the primary solids of pyramid and cube. It is possible to read the curving edge of Michelangelo's St Peter's, which Le Corbusier draws in The Lesson of Rome, as the outer edge of the Ville Contemporaine. The poche of Michelangelo's St Peters merges into the rational blocks of the city, while the nave is extruded longitudinally to spatially push the Ville Contemporaine central axis outward. Gabriele Mastrigli has noted that when Le Corbusier redraws Michelangelo's plan in Toward an Architecture, the distilled outline without the nave is rescaled and duplicated as the Station plan at the centre of the Ville Contemporaine. ${ }^{14}$ It is interesting to note the

\footnotetext{
${ }^{13}$ Le Corbusier comments that the Ville Contemporaine was a theoretical project to develop principles of a modern urbanism. See Le Corbusier, The City of Tomorrow and Its Planning, trans. by Frederich Etchells (New York: Dover, 1987), pp. 169-170.

${ }^{14}$ Refer Gabriele Mastrigli, 'In Praise of Discontinuity', in Visionary Power: Producing the Contemporary City, ed. by Christine de Baan, Joachim Declerck, and Véronique Patteeuw (Rotterdam: NAi Publishers, 2007), pp. 112-24. Mastrigli has noted how the redents proportion recalls that of Charles Fourier's Phalanstery and how the spatial enclosure is related to Versailles.
} 
telescoping of scales as a formal strategy and that this process is further developed in the individual cruciform towers that define the Central Station. ${ }^{15}$ Bramante's plan of St Peter's articulates the centralised plan as a cross, which Le Corbusier inverts void into the solid of a single cruciform tower and transposes this to the Ville Contemporaine. The poche of Bramante's interior becomes the edge that articulates each slab of the cruciform. The process reveals an associative and syntactic analogical approach that moves from a strategic and compositional strategy at the scale of the city to a formal device at the scale of the architectural object.

The strategy is also apparent in a comparison of the central section of the Ville Contemporaine and Piranesi's Castel Sant'Angelo complex in the Campo Marzio. As Mastrigli has observed, there is a similarity between the frontispiece to Piranesi's Campo Marzio view of the Castel Sant'Angelo and Le Corbusier's aerial view of the Central Station in the Ville Contemporaine. Both share an oblique elevated viewing position, especially when Piranesi's etching is flipped. Le Corbusier does not reproduce the historical elements but rearticulates Piranesi's principles of composition: the axial relationship, point of view and formal syntax. These principles are present first in the way Le Corbusier replaces the paired circus elements that surround the Castel Sant'Angelo complex with paired canopies at the Central Station. These are distilled into a few simple lines. Then secondly in the principle of the axis at Castel Sant'Angelo, which in the Ville Contemporaine substitute for the central infrastructural spine intersecting the station.

\footnotetext{
${ }^{15}$ Scaling as a critical strategy is articulated in Le Corbusier's urban projects in South America and at Algiers. In particular in a sketch for a project in Buenos Aires in 1929, Le Corbusier takes the cruciform tower of Ville Contemporaine and extrudes it horizontally like a linear city; or as can be seen in Le Corbusier's sketch plan of Villa Savoye the curving elements of the roof terrace become the curving redents at Algiers. Scaling is closely linked to association as a strategy and we could project an associative chain in Le Corbusier's projects which disarticulate and rearticulate the material of the voyage and the Lesson of Rome, to the projects of the Ville Contemporaine disarticulated into the Plan Voisin. The cruciform tower embedded in the fabric of Plan Voisin is transformed into the linear city of the South America projects. These themes condense at the Algiers Plan Obus.
} 
There is more to connect Piranesi and Le Corbusier. Le Corbusier's canonical perspective drawing that looks toward the cruciform towers and along the highway recalls Piranesi's view of Piazza del Popolo. Piranesi draws the twin churches beyond the obelisk at the edge of the piazza. Le Corbusier replaces the twin churches with cruciform towers, while the obelisk is shifted to one side. ${ }^{16}$ The graphic language of intense mark making and the flowing lines employed for the street suggest the movement that in Le Corbusier drawing is represented by the cars traveling along the highway.

A last comparison can demonstrate the resonance between Piranesi’s Campo Marzio and the Ville Contemporaine. In a study by Le Corbusier for the Plan Voisin, in which the Ville Contemporaine is disarticulated and rearticulated for the centre of Paris, Le Corbusier shows the cruciform towers of his Ville Contemporaine as the backdrop to the primary monuments of Paris: the Eiffel Tower, Arc de Triumphe, Sacra Couer, the Louvre, the Pantheon, and Notre Dame. ${ }^{17}$ These monuments become points of reference within the city and recall the selection of singularities from Le Corbusier's Lesson of Rome. This sketch resonates with Piranesi's etching of the Scenographia of the Campo Marzio in which a cluster of monuments - the ground of Piazza Navona, the Pantheon, the Coliseum - are isolated on the site. In Le Corbusier's sketch and Piranesi etching there is an anticipation of the critique of ground that Rossi would explore, where it is undecidable if the monuments are liberated from the ground to be repositioned in other contexts or positioned on the site as singular forms to redefine the development of the city.

\section{Conclusion: The Linguistic Form of the City}

The analogue is a linguistic form. The analogue assimilates history, transforms its language and develops the material into singular forms for combination and recombination. Piranesi

\footnotetext{
${ }^{16}$ A version of Carlo Rainaldi's twin churches is evident as twinned circular elements at the convergence of roads to the west edge of the Ville Contemporaine plan.

${ }^{17}$ Refer Le Corbusier, Precisions on the Present State of Architecture and City Planning, trans. by Edith Schreiber Aujame (Zürich: Park Books, 2015).
} 
exaggerates the singularity of architecture in the figure-figure relationships of the Campo Marzio Ichnographia. Le Corbusier and Rossi distil an architectural language to the bare essentials, 'limited to a few words... which possess infinite meaning.' The analogue as a linguistic form is not devoid of content but condense formal associations. The 'infinite meaning' that Le Corbusier refers to is architecture's history, its forms and elements, texts and drawings, principles and approaches in a constant dialogue, embodied in the singularity of the analogue. The analogue becomes a critical device to deepen and intensify architecture's relationship to the city. The analogue is situated between authorship and the collective imagination, analysis and project, theory and method. A rereading of the analogical city as a linguistic form, its categories and project genealogies helps to redefine contemporary discourse on architecture and the city. Against the current instrumental language of efficiency and performance, there is a need to rearticulate formal knowledge and an historical consciousness and to reassert a linguistic approach to architecture and the city as a critical project. A redefined and rewritten analogical city is one model.

\section{References}

Colomina, Beatriz (1994), Privacy and Publicity: Modern Architecture as Mass Media, Cambridge, Mass.: MIT Press.

Hendrix, J. S., and Holm, L. E., (eds) (2016), Architecture and the Unconscious, London: Routledge.

Le Corbusier (2015), Precisions on the Present State of Architecture and City Planning [1930] (trans. Edith Schreiber Aujame), Zürich: Park Books.

_ (1987), The City of Tomorrow and Its Planning [1929] (trans. Frederich

Etchells), New York: Dover. 
_ (2008), Toward an Architecture [1923] (trans. John Goodman), London:

Frances Lincoln.

Le Corbusier (Charles-Edouard Jeanneret) (2007), Journey to the East [1966] (ed. \& trans. Ivan Zaknic), Cambridge, Mass.: The MIT Press.

Mastrigli, Gabriele (2007), 'In Praise of Discontinuity', in C. de Baan, J. Declerck, and V. Patteeuw (eds), Visionary Power: Producing the Contemporary City, Rotterdam: NAi Publishers, pp. 112-24.

Rossi, Aldo (1981), A Scientific Autobiography (trans. Lawrence Venuti), Cambridge, Mass.: MIT Press.

(1982), The Architecture of the City [1966] (trans. Diane Ghirardo and Joan Ockman), Cambridge, Mass.: MIT Press.

_ (1976), 'La Città Analoga: Tavola / The Analogous City: Panel', Lotus International, 13, pp. 4-9.

_ (1989), 'Introduction to “Architecture, Essai Sur L'art”' [1967], UCLA Architecture Journal, 2, pp. 40-49.

von Moos, Stanislaus (2009), Le Corbusier: Elements of a Synthesis, Rotterdam: 010 Publishers.

von Moos, S., and Rüegg A., (eds) (2002), Le Corbusier Before Le Corbusier: Applied Arts, Architecture, Painting and Photography, 1907-1922, New Haven: Yale University Press. 

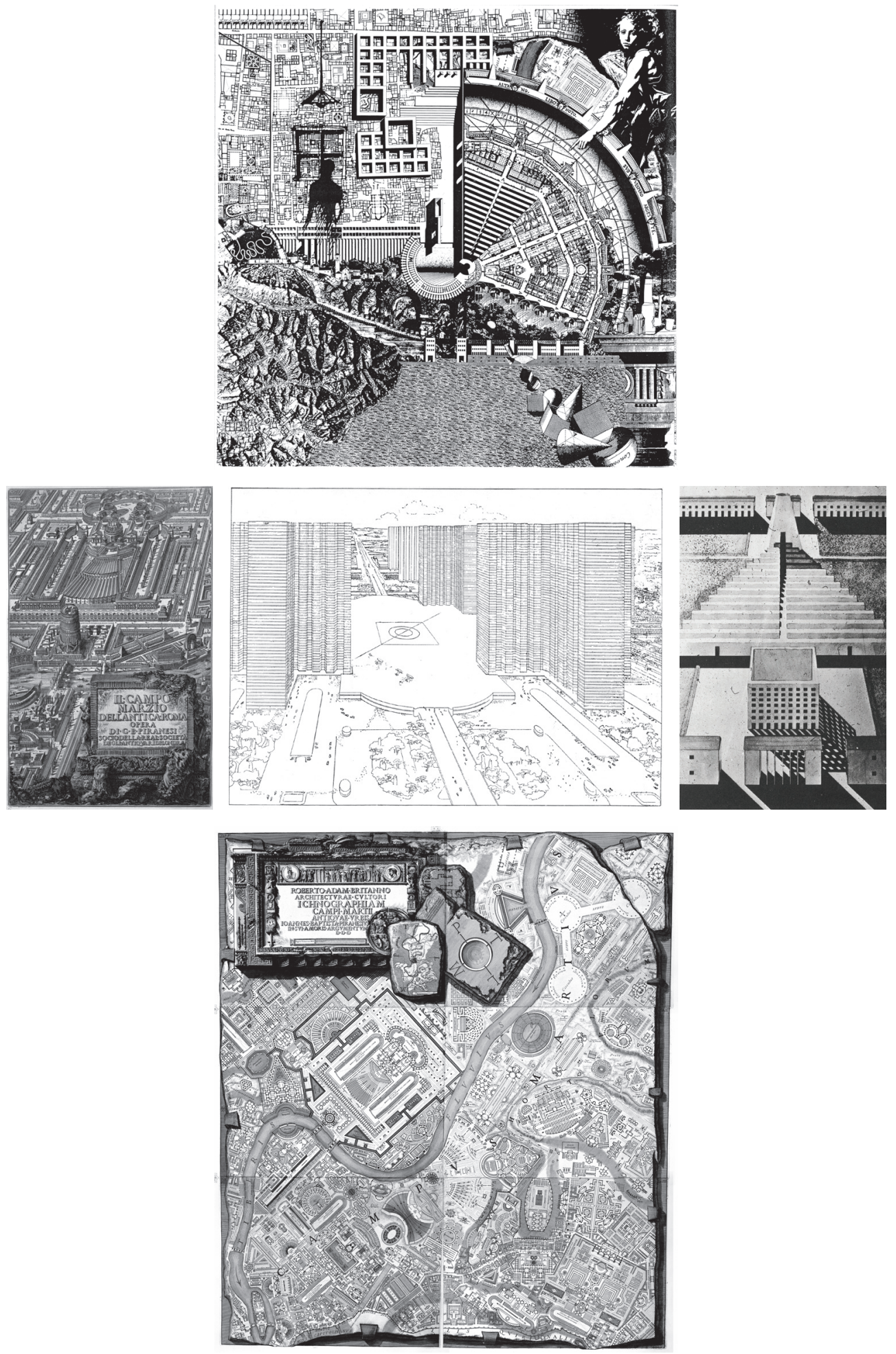

Figure 1. Montage panel by author showing Giovanni Battista Piranesi's Campo Marzio Ichnographia and Aldo Rossi's Analogical City: Panel with Piranesi's Frontispiece adjacent to Le Corbusier's perspective view of the Ville Contemporaine Central Station and Rossi's study for Modena Cemetery. 


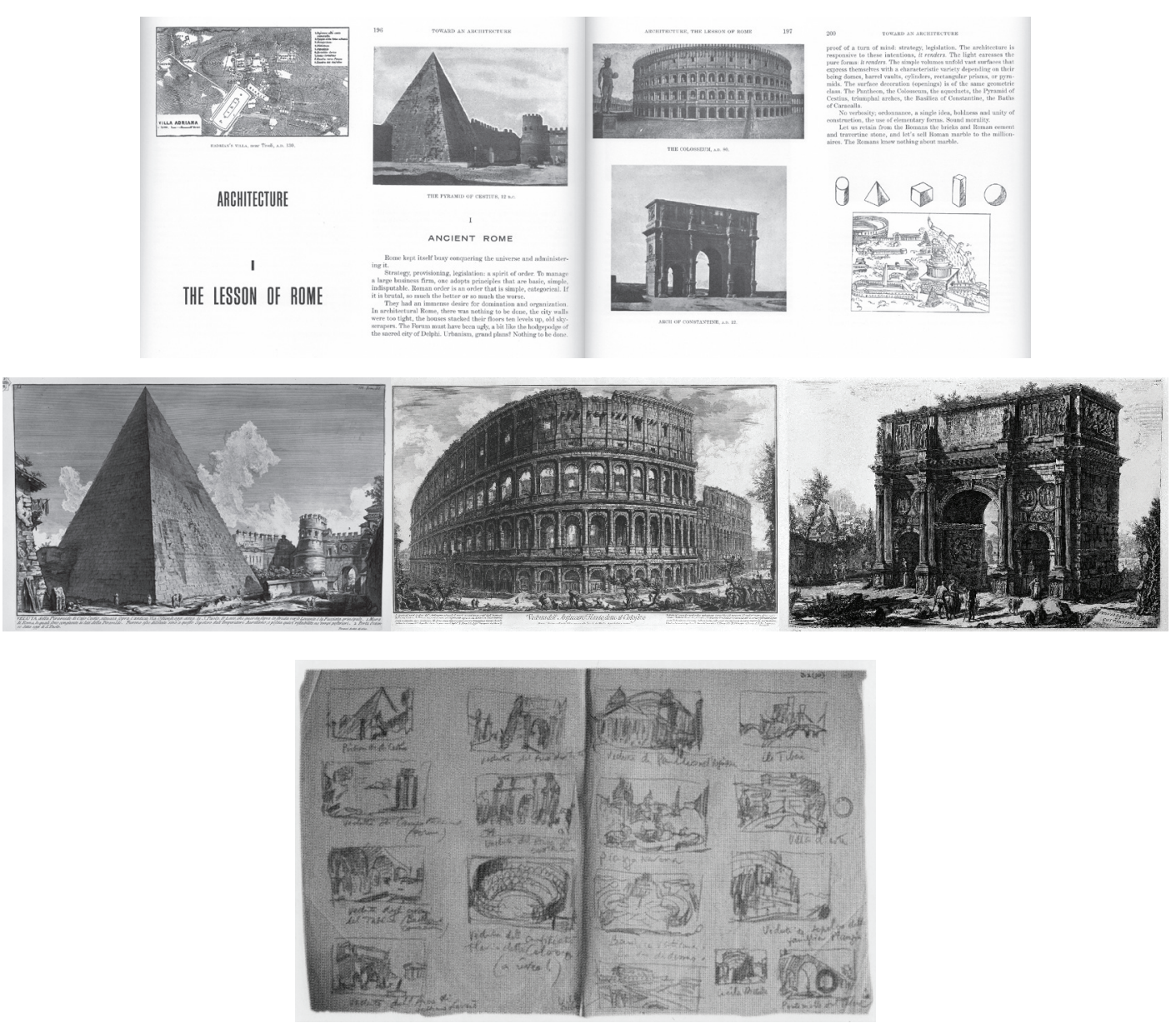

Figure 2. Montage panel by author showing page spreads from 'The Lesson of Rome' in Le Corbusier's Toward an Architecture with panels from Giovanni Battista Piranesi's 'Veduta di Roma' and Le Corbusier's studies of the vedute. 


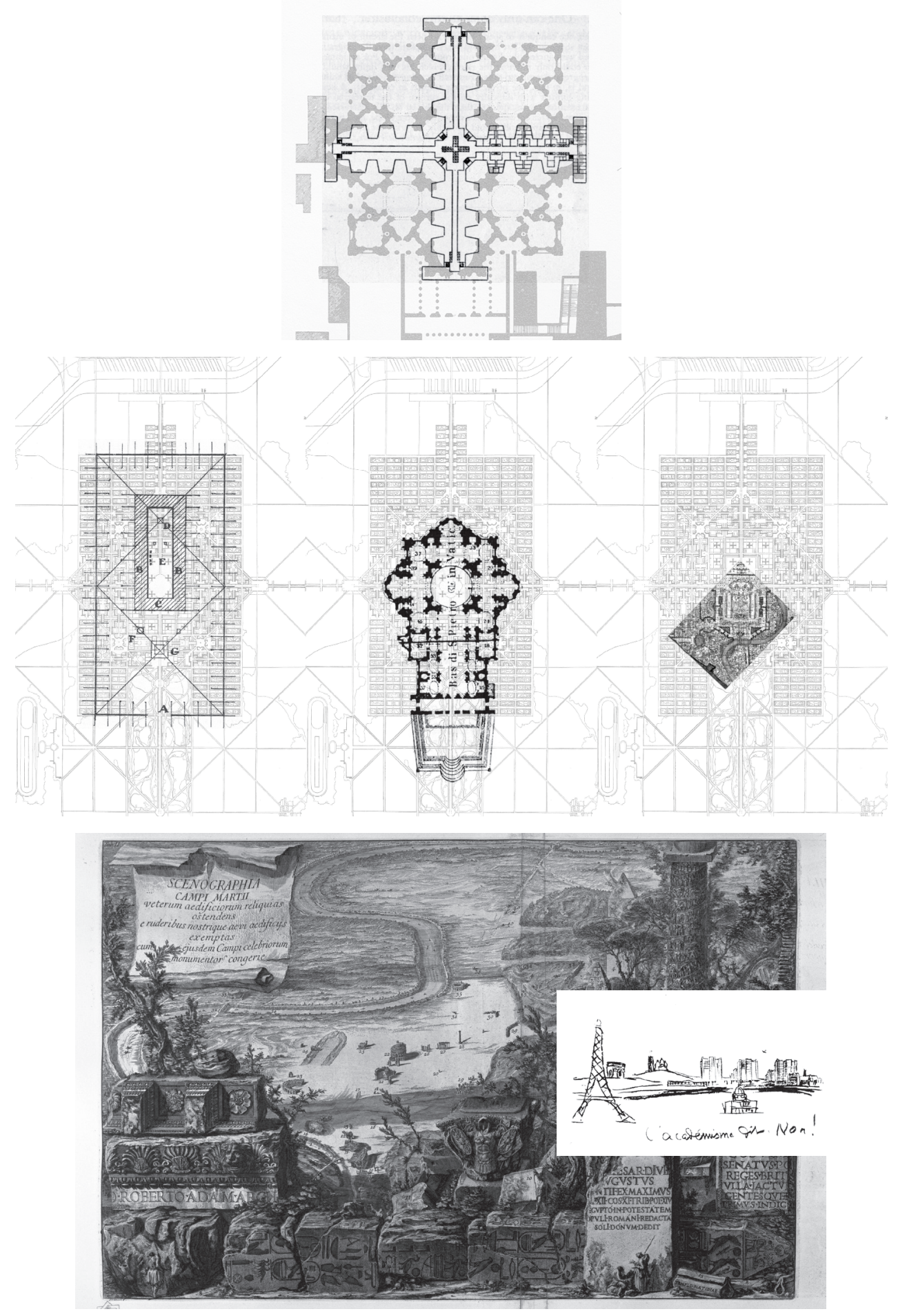

Figure 3. Montage panel by author showing relationship between the Ville Contemporaine plan and its analogues: the regulating lines of the temple, Michelangelo's St Peter's and the Castel Sant'Angelo section of Piranesi's Campo Marzio. Le Corbusier's cruciform tower is montaged with Bramante's St Peter's and Le Corbusier's study of the Plan Voisin coincides with Piranesi's Scenographia.. 


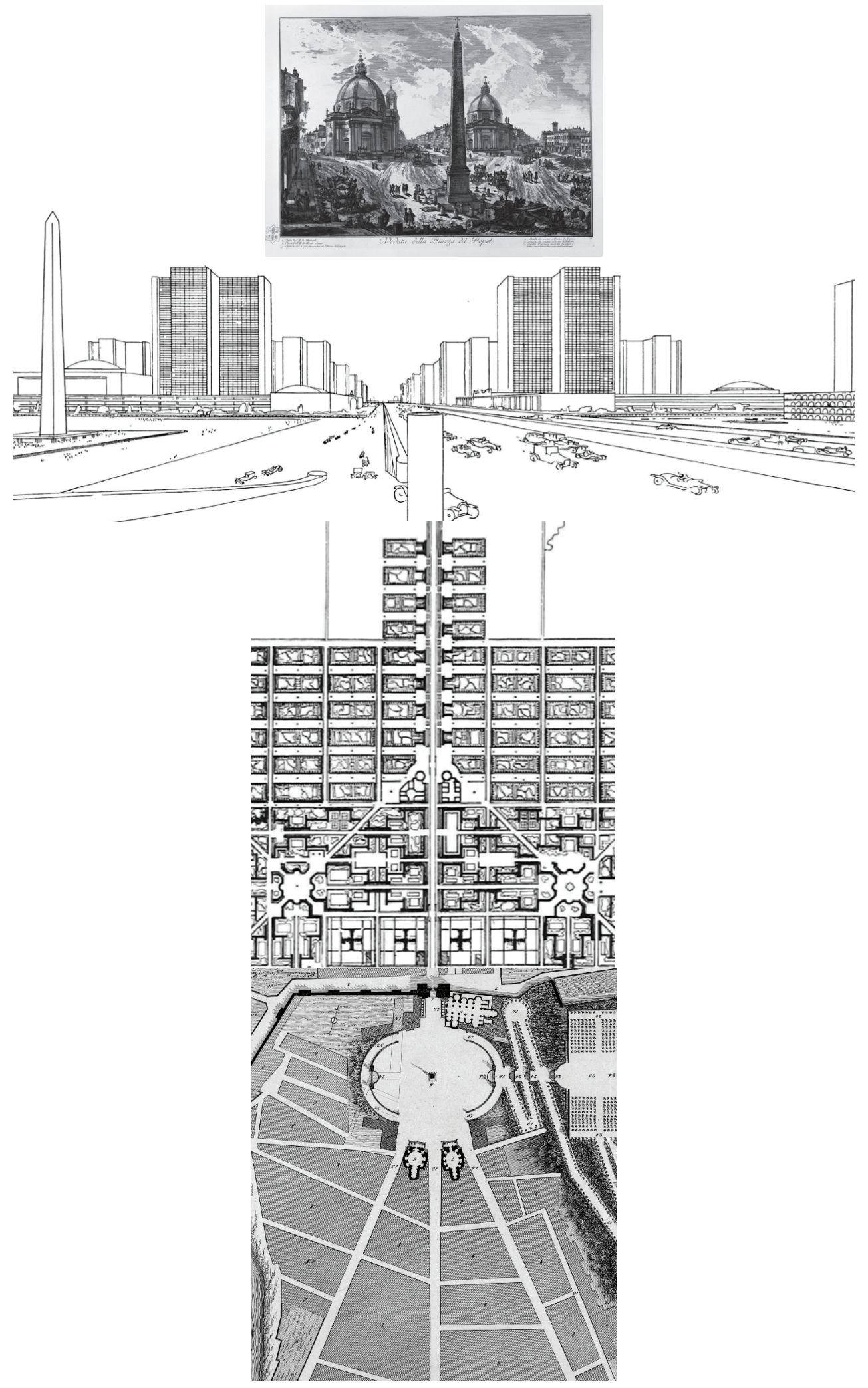

Figure 4. Montage panel by author showing Le Corbusier's substitution of elements from Piranesi's veduta of Piazza del Popolo to construct the Ville Contemporaine perspective and plan. 